\title{
Front Matter: Volume 10670
}

, "Front Matter: Volume 10670," Proc. SPIE 10670, Real-Time Image and Video Processing 2018, 1067001 (25 June 2018); doi: 10.1117/12.2502372

SPIE Event: SPIE Commercial + Scientific Sensing and Imaging, 2018, Orlando, FL, United States 


\title{
PROCEEDINGS OF SPIE
}

\section{Real-Time Image and Video Processing 2018}

\author{
Nasser Kehtarnavaz \\ Matthias F. Carlsohn \\ Editors
}

16-17 April 2018

Orlando, Florida, United States

Sponsored and Published by

SPIE 
The papers in this volume were part of the technical conference cited on the cover and title page. Papers were selected and subject to review by the editors and conference program committee. Some conference presentations may not be available for publication. Additional papers and presentation recordings may be available online in the SPIE Digital Library at SPIEDigitalLibrary.org.

The papers reflect the work and thoughts of the authors and are published herein as submitted. The publisher is not responsible for the validity of the information or for any outcomes resulting from reliance thereon.

Please use the following format to cite material from these proceedings:

Author(s), "Title of Paper," in Real-Time Image and Video Processing 2018, edited by

Nasser Kehtarnavaz, Matthias F. Carlsohn, Proceedings of SPIE Vol. 10670 (SPIE, Bellingham, WA, 2018) Seven-digit Article CID Number.

ISSN: 0277-786X

ISSN: 1996-756X (electronic)

ISBN: 9781510618510

ISBN: 9781510618527 (electronic)

Published by

SPIE

P.O. Box 10, Bellingham, Washington 98227-0010 USA

Telephone +1 3606763290 (Pacific Time) · Fax +1 3606471445

SPIE.org

Copyright (C) 2018, Society of Photo-Optical Instrumentation Engineers.

Copying of material in this book for internal or personal use, or for the internal or personal use of specific clients, beyond the fair use provisions granted by the U.S. Copyright Law is authorized by SPIE subject to payment of copying fees. The Transactional Reporting Service base fee for this volume is $\$ 18.00$ per article (or portion thereof), which should be paid directly to the Copyright Clearance Center (CCC), 222 Rosewood Drive, Danvers, MA 01923. Payment may also be made electronically through CCC Online at copyright.com. Other copying for republication, resale, advertising or promotion, or any form of systematic or multiple reproduction of any material in this book is prohibited except with permission in writing from the publisher. The CCC fee code is 0277$786 \mathrm{X} / 18 / \$ 18.00$.

Printed in the United States of America.

Publication of record for individual papers is online in the SPIE Digital Library.

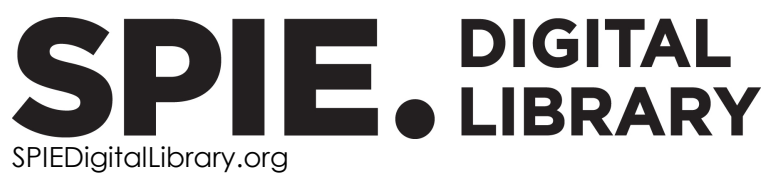

Paper Numbering: Proceedings of SPIE follow an e-First publication model. A unique citation identifier (CID) number is assigned to each article at the time of publication. Utilization of CIDs allows articles to be fully citable as soon as they are published online, and connects the same identifier to all online and print versions of the publication. SPIE uses a seven-digit CID article numbering system structured as follows:

- The first five digits correspond to the SPIE volume number.

- The last two digits indicate publication order within the volume using a Base 36 numbering system employing both numerals and letters. These two-number sets start with $00,01,02,03,04$, 05, 06, 07, 08, 09, 0A, OB ... 0Z, followed by 10-1Z, 20-2Z, etc. The CID Number appears on each page of the manuscript. 


\section{Contents}

$\checkmark \quad$ Authors

vii Conference Committee

SESSION 1 REAL-TIME ALGORITHMS I

1067002 On the parallel classification system using hyperspectral images for remote sensing applications [10670-1]

1067003 Robust enhancement technique for color images corrupted by impulsive noise [10670-2]

$1067004 \quad$ Blind image sharpness metric based on edge and texture features [10670-3]

1067005 Extraction of vital signs using real time video analysis for neonatal monitoring [10670-4]

1067006 Real time demosaicking and superresolution of multispectral images [10670-5]

SESSION 2 REAL-TIME HARDWARE IMPLEMENTATION

$1067007 \quad$ An efficient dense descriptor applied to 3D vision implemented on parallel computing [10670-6]

1067008 Computationally efficient blood vessels segmentation in fundus image on shared memory parallel machines [10670-7]

10670 OA A high-speed driver for silicon photonics Mach-Zehnder modulator for high data-rate transfer of particle collision images in high-energy physics and in medical physics [10670-9]

\section{SESSION 3 REAL-TIME ALGORITHMS II}

$10670 \mathrm{OB} \quad$ A computationally efficient pipeline for 3D point cloud reconstruction from video sequences [10670-10]

10670 OC Real-time lung segmentation from whole-body CT scans using Adaptive Vision Studio: a visual programming software suite [10670-11]

10670 OD Evolutionary cortical surface segmentation [10670-12]

10670 OF Performance analysis of real-time DNN inference on Raspberry Pi [10670-14] 
$106700 \mathrm{G}$ Computational efficiency of optic disk detection on fundus image: a survey [10670-15]

$10670 \mathrm{OH}$ Impact of segment size on dynamic adaptive video streaming over HTTP (DASH) over LAN network [10670-16]

1067001 Real-time image and video processing for advanced services on-board vehicles for passenger transport [10670-17]

\section{POSTER SESSION}

10670 0J Real-time kinematics for accurate geolocalization of images in telerobotic applications [10670-18]

$10670 \mathrm{OL} \quad$ Real-time stereovision framework for underwater drone maneuvering [10670-20]

10670 OM Person re-identification by semi-supervised dictionary rectification learning [10670-21]

10670 ON A vehicle real-time detection algorithm based on YOLOv2 framework [10670-22]

1067000 A sparse dimension-reduction based person re-identification algorithm [10670-23]

10670 OP Discriminative deep transfer metric learning for cross-scenario person re-identification [10670-24] 


\section{Authors}

Numbers in the index correspond to the last two digits of the seven-digit citation identifier (CID) article numbering system used in Proceedings of SPIE. The first five digits reflect the volume number. Base 36 numbering is employed for the last two digits and indicates the order of articles within the volume. Numbers start with 00, 01, 02, 03, 04, 05, 06, 07, 08, 09, OA, OB...0Z, followed by 10-12, 20-2Z, etc.

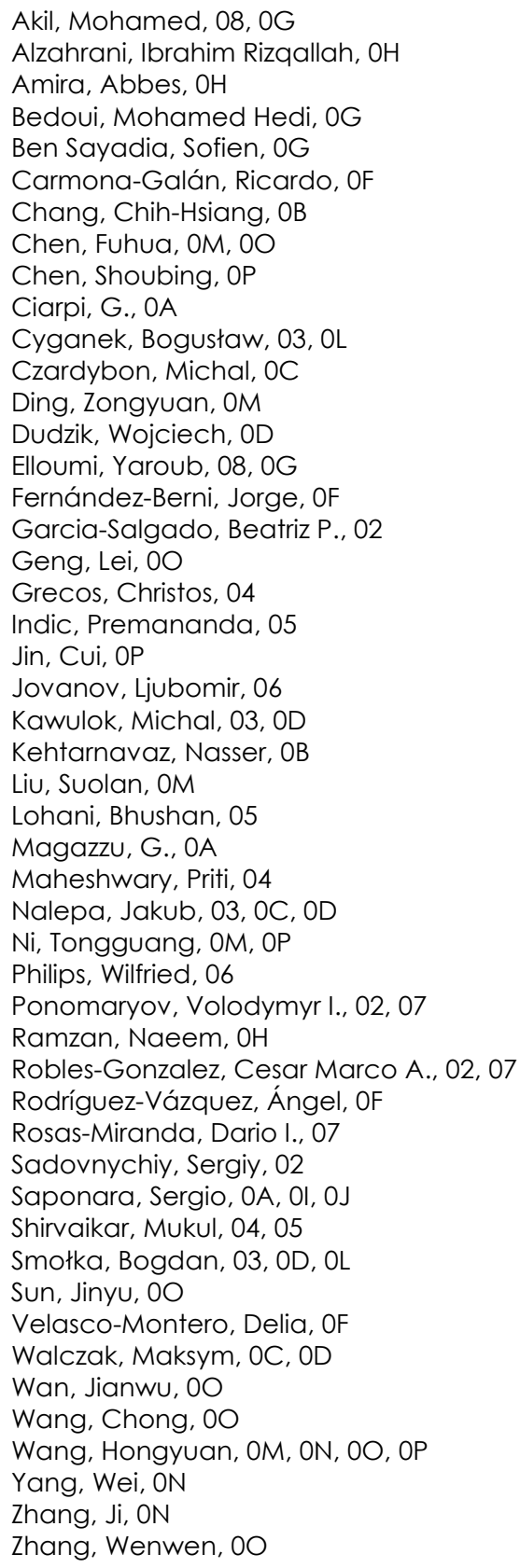


Proc. of SPIE Vol. $106701067001-6$

Downloaded From: https://www.spiedigitallibrary.org/conference-proceedings-of-spie on 26 Apr 2023 Terms of Use: https://www.spiedigitallibrary.org/terms-of-use 


\title{
Conference Committee
}

\author{
Symposium Chair \\ Robert D. Fiete, Harris Corporation (United States) \\ Symposium Co-chair \\ Jay Kumler, JENOPTIK Optical Systems, LLC (United States) \\ Conference Chairs
}

Nasser Kehtarnavaz, The University of Texas at Dallas (United States)

Matthias F. Carlsohn, Computer Vision and Image Communication at Bremen (Germany)

Conference Program Committee

Mohamed Akil, ESIEE (France)

Guillermo Botella, Universidad Complutense de Madrid (Spain)

Philip P. Dang, U.S. Department of Commerce (United States)

Touradj Ebrahimi, Ecole Polytechnique Fédérale de Lausanne (Switzerland)

Barak Fishbain, Technion-Israel Institute of Technology (Israel)

Sergio R. Goma, Qualcomm Inc. (United States)

Christos Grecos, Central Washington University (United States)

Reinhard Koch, Christian-Albrechts-Universität zu Kiel (Germany)

Volodymyr Ponomaryov, Instituto Politécnico Nacional (Mexico)

Luis Salgado, Universidad Politécnica de Madrid (Spain)

Sergio Saponara, Università di Pisa (Italy)

Mukul V. Shirvaikar, The University of Texas at Tyler (United States)

Athanassios N. Skodras, University of Patras (Greece)

Bogdan Smolka, Silesian University of Technology (Poland)

Session Chairs

1 Real-Time Algorithms I

Nasser Kehtarnavaz, The University of Texas at Dallas (United States)

2 Real-Time Hardware Implementation

Mukul V. Shirvaikar, The University of Texas at Tyler (United States)

3 Real-Time Algorithms II

Matthias F. Carlsohn, Computer Vision and Image Communication at Bremen (Germany) 
4 Real-Time Video Systems

Christos Grecos, Central Washington University (United States)

viii

Proc. of SPIE Vol. $106701067001-8$

Downloaded From: https://www.spiedigitallibrary.org/conference-proceedings-of-spie on 26 Apr 2023 Terms of Use: https://www.spiedigitallibrary.org/terms-of-use 